\title{
Pengaruh Model Example Non Example Terhadap Kemampuan Pemahaman Konsep Bangun Datar pada Siswa Kelas IV di Sekolah Dasar
}

\author{
Ayu Fitri \\ Pendidikan Guru Sekolah Dasar (PGSD), FKIP Universitas Buana Perjuangan, INDONESIA \\ e-mail: ayufitri@ubpkarawang.ac.id \\ The Effect of Non Example Example Models on the Ability to Understanding \\ Flat Build Concepts in Class IV Students in Primary Schools
}

\section{Kata Kunci \\ Pembelajaran Example Non Example, Kemampuan Pemahaman Matematis}

\section{Keywords:}

Learning Non Example Example, Mathematical Understanding Skill

\begin{abstract}
Abstrak
Penelitian ini dilatar belakangi oleh pembelajaran matematika adalah masih rendahnya daya serap dan pemahaman siswa terhadap konsep matematika, keterlibatan siswa dalam pembelajaran matematika belum maksimal, siswa masih asyik dengan dunianya sendiri dengan tidak memperhatikan penjelasan materi yang diberikan oleh guru. Metode penelitian ini menggunakan pendekatan kuantitatif. Populasi yang digunakan adalah siswa kelas IV SDN Kertasari I, Sampel pada penelitian ini kelas IVA sebagai eksperimen dan kelas IVB sebagai kelas kontrol. Adapun hasil penelitian ini kelas IV A (kelas eksperimen) memperoleh rata- rata 81,833 dengan variansi 153,316 dan standar deviasi 12,382. Sedangkan kelas IVB (kelas Kontrol) memperoleh ratarata 74,031 dengan variansi 198,096 dan standar deviasi 14,075. Sehingga terdapat pengaruh model pembelajaran Example Non Example terhadap kemampuan pemahaman konsep matematika siswa di kelas SD Negeri Kertasari 1. Hal ini dibuktikan dengan hasil uji-t yang diperoleh $=2,311$ dan 2,000 .
\end{abstract}

\section{Abstract:}

This research is motivated by the learning of mathematics is the low absorption and understanding of students towards mathematical concepts, student involvement in learning mathematics is not optimal, students are still preoccupied with their own world by not paying attention to the explanation of the material provided by the teacher. This research method uses a quantitative approach. The population used was grade IV students of SDN Kertasari I, the sample in this study was class IVA as an experiment and class IVB as a control class. The results of this study class IV A (experimental class) obtained an average of 81.833 with a variance of 153.316 and a standard deviation of 12.382 . Whereas the IVB class (Control class) obtained an average of 74,031 with a variance of 198,096 and a standard deviation of 14,075. So that there is an influence of the Non Non Example learning model on the ability to understand the mathematical concepts of students in the SD Negeri Kertasari 1 class. This is evidenced by the results of the t-test obtained $=$ 2,311 and 2,000 .

Article History:

Received : 11Desember 2019

Revised : 7Januari 2020

Accepted : 10Februari 2020 
The Effect of Non Example Example Models on the Ability to Understanding Flat Build Concepts in Class IV Students in Primary Schools

\section{Pendahuluan}

Matematika merupakan ilmu yang penting dipelajari karena sering digunakan dalam kehidupan sehari-hari, meningkat kemampuan berpikir logis, ketelitian dan kesadaran keruangan, serta memberikan kemampuan terhadap usaha memecahkan masalah yang menantang. Sejalan dengan pengertian matematika yang dikemukakan oleh Amir dan Risnawati (2016 : 9) bahwa matematika adalah cara berpikir logis yang dipresentasikan dalam bilangan, ruang, dan bentuk dengan aturan-aturan yang telah ada yang tak lepas dari aktivitas insani.

Salah satu aspek yang terkandung dalam pembelajaran matematika adalah konsep. Konsep merupakan batu pembangunan berpikir. Konsep merupakan dasar bagi proses mental yang lebih tinggi untuk merumuskan prinsip dan generalisasi. Pentingnya kemampuan pemahaman konsep matematika siswa adalah hamper semua teori belajar menjadikan sebagai tujuan dari proses pembelajaran. Pembelajaran diarahkan untuk pemahaman konsep dan prinsip matematika yang kemudian diperlukan untuk menyelesaikan masalah, masalah dalam disiplin ilmu, dan masalah dalam kehidupan sehari-hari. Dengan pemahaman konsep yang baik, siswa akan mudah mengingat, menggunakan dan menyusun kembali suatu konsep yang telah dipelajari serta dapat menyelesaikan berbagai variasi matematika.

Berdasarkan hasil observasi yang dilakukan di SD Negeri Kertasari I Rengasdengklok bahwa salah satu masalah pokok dalam pembelajaran matematika adalah masih rendahnya daya serap dan pemahaman siswa terhadap konsep matematika, keterlibatan siswa dalam pembelajaran matematika belum maksimal, siswa masih asyik dengan dunianya sendiri dengan tidak memperhatikan penjelasan materi yang diberikan oleh guru. Rendahnya kemampuan pemahaman konsep matematika terlihat dari proses belajar matematika siswa yang masih mengalami kesulitan dalam mengungkapkan ide atau pandanganya sendiri untuk menemukan solusi pemecahan masalah martematika dari soal yabng diberikan, serta disea merasa kesulitan dalam menyelesaikan soal-soal yang diberikan oleh guru misalnya dalam menerapkan rumus matematika.

Pemahaman merupakan salah satu tujuan penting dalam pembelajaran matematika. Pemahaman berasal dari akar kata paham, yang menurut Kamus Besar Bahasa Indonesia berarti sebagai pengetahuan banyak, pendapat, aliran, mengerti benar. Pemahaman dalam proses pembelajaran berarti siswa dapat mengerti apa yang telah diajarkan oleh guru. Sejalan dengan Dimyati dan Mudijono (2006:27) bahwa "Pemahaman adalah mencakup kemampuan menangkap arti dan makna tentang hal yang dipelajari”. Pemahaman merupakan tingkat kemampuan yang mengharapkan seseorang mampu memahami arti atau konsep, situasi serta fakta yang diketahuinya. Dalam hal ini siswa tidak hanya hafal secara verbalitas, tetapi memahami konsep dari masalah atau fakta yang ditanyakan. Maka operasionalya dapat membedakan, mengubah, mempersiapkan, menyajikan, mengatur, menginterprestasikan, menjelaskan, mendemonstrasikan, memberi contoh, memperkirakan, menjelaskan, mendemonstasikan, memberi contoh, memperkirakan, menentukan, dan mengambil keputusan.

Sedangkan konsep adalah balok-balok bangunan dasar untuk berpikir dan berkomunikasi (Arends, 2008:322). Menurut Mustafa (Hamalik, 2003:162) bahwa konsep adalah suatu kategori stimulti yang memiliki ciri-ciri umum, stimulti adalah objek-objek, kejadian-kejadian, kegiatankegiatan, atau hubungan-hubungan yang mempunyai atribut-atribut yang sama. Jadi konsep yakni suatu pemikiran objek yang abstrak dan memiliki kriteria tertentu.

Konsep juga diartikan sebagai suatu ide abstrak tentang objek atau kejadian yang dibentuk dengan memandang sifat-sifat yang sama dari sekumpulan objek, sehingga seseorang dapat mengelompokkan atau mengklasifikasikan objek atau kejadian sekaligus menerangkan apakah objek tersebut merupakan contoh atau bukan contoh dari pengertian tersebut. Konsep merujuk pada pemahaman dasar. Siswa mengembangkan suatu konsep ketika mereka mampu mengklasifikasikan atau mengelompokkan benda-benda atau ketika mereka dapat mengasosiasikan suatu nama dengan kelompok benda tertentu. Dapat disimpulkan bahwa konsep adalah suatu ide abstrak dalam mengelompokkan kejadian atau kegiatan tertentu. 
Kemampuan pemahaman konsep dalam pembelajaran matematika merupakan kompetensi yang ditunjukkan siswa dalam memahami konsep dan dalam melakukan prosedur secara luwes, akurat, efisien, dan tepat. Pemahaman konsep sangat penting dalam pembelajaran matematika tercantum dalam BNSP (2006) tentang tujuan pembelajaran matematika di sekolah dasar yaitu: (1) memahami konsep matematika, menjelaskan keterkaitan anatrkonsep dan mengaplikasikan konsep atau algoritma secara luwes, akurat, efisien, dan tepat dalam pemecahan masalah; (2) menggunakan penalaran pada pola dan sifar, melalkukan manipulasi matematika dalam membuat generalisasi, menyusun bukti atau menjelaskan gagasan dan pernyataan matematika; (3) memecahkan masalah yang meliputi kemampuan memahami masalah, merancang model matematia, menyelesaikan model dan mendafsirkan solusi yang diperoleh; (4) mengkomunikasikan gagasan dengna symbol, tabel, diagram, atau media lain untuk memperjelas keadaan atau masalah; (5) memiliki sikap menghargai kegunaan matematika dalam kehidupan, yaitu memiliki rasa ingin tahum perhatian, dan minat dalam mempelajari matematika, serta sikap ulet dan percaya diri dalam pemecahan masalah.

Pemahaman konsep merupakan kompetensi yang ditunjukkan siswa dalam memahami konsep dan dalam prosedur yang luwes, akurat, efisien dan tepat. Indikator pemahaman konsep menurut Shadiq (2009:13) sebagai berikut:

1. Mengklasifikasi objek-objek menurut sifat-sifat tertentu (sesuai dengan konsepnya)

2. Memberikan contoh dan non contoh dari konsep

3. Memberikan konsep dalam berbagai bentuk representasi matematis

4. Mengembangkan syarat perlu dan cukup suatu konsep

5. Menggunakan, memanfaatkan dan memilih prosedur atau operasi tertentu

6. Mengaplikasikan konsep atau alogaritma pemecahan masalah

Untuk mengatasi permasalahan dalam proses pembelajaran matematika di sekolah maka guru memerlukan terobosan baru dalam memperbaiki kemampuan pemahaman konsep matematika dengan model pembelajaran example non example.

Example non example adalah metode belajar yang menggunakan contoh-contoh (Hamdani, 2011:94). Model pembelajaran example non example bertujuan untuk mendorong siswa agar belajar kritis dengan jalan memecahkan permasalahan-permasalahan yang terkandung dalam contoh-contoh yang telah disiapkan terlebih dahulu.

Model pembelajaran example non example merupakan sebuah langkah untuk mensiasati agar siswa dapat mendefinisikan konsep. Adapun strategi yang biasa digunakan bertujuan untuk mempersiapkan siswa secara cepat dengan menggunakan 2 hal yang terdiri dari Example (contoh akan suatu materi yang sedang dibahas) dan non example (contoh akan suatu materi yang tidak sedang dibahas) dan meminta.

Menurut Bruce Joyce, Masha Weil, dan Emily Calhoun (2009) bahwa model pembelajaran yang menggunakan gambar sebagai media pembelajaran. Penggunaan media gambar ini disusun dan dirancang agar anak dapat menganalisis gambar tersebut menjadi sebuah bentuk deskripsi singkat mengenai apa yang ada didalam gambar. Penggunaan model example non example ini lebih menekankan pada konteks analisis siswa. Model pembelajaran example non example menggunakan gambar dapat melalui OHP, proyektor, atau media yang paling sederhana yaitu poster. Gambar yang kita gunakan haruslah jelas dan kelihatan dari jarak jauh, sehingga anak yang berada dibelakang dapat juga melihat dengan jelas.

Menurut Suprijono (2011:125) bahwa langkah-langkah model pembelajaran Example Non Example sebagai berikut:

1. Guru mempersiapkan gambar-gambar tentang permasalahan yang sesuai dengan tujuan pembelajaran. 
The Effect of Non Example Example Models on the Ability to Understanding Flat Build Concepts in Class IV Students in Primary Schools

2. Guru menempelkan gambar di papan atau ditayangan melalui proyektor.

3. Guru memberikan petunjuk dan memberi kesempatan pada siswa untuk memerhatikan/menganalisis permasalahan yang ada dalam gambar.

4. Melalui diskusi 2-3 orang siswa, hasil diskusi dari analisis masalah dalam gambar tersebut dicatat pada kertas.

5. Tiap kelompok diberi kesempatan membacakan hasil diskusinya.

6. Mulai dari komentar/hasil diskusi siswa, guru mulai menjelaskan materi sesuai tujuan yang ingin dicapai.

7. Kesimpulan.

Adapun kelebihan dan kekurangan model pembelajaran example non example yang dikemukakan oleh Bruce, Well \& Emily (2009:76) sebagai berikut:

Kelebihan model pembelajaran example non example ialah (1) siswa lebih kritis dalam menganalisis gambar, (2) siswa mengetahui aplikasi dan materi berupa contoh gambar, (3) siswa diberi kesempatan untuk mengemukakan pendapatnya.

Kekurangan model pembelajaran example non example ialah (1) tidak semua materi dapat disajikan dalam bentuk gambar, (2) memakan waktu yang lama.

Salah satu kekurangan model pembelajaran example non example tidak semua materi dapat menggunakan model pembelajaran ini maka materi yang akan diambil ialah bangun datar di kelas IV sekolah dasar.

Berdasarkan latar belakang diatas peneliti melakukan penelitian dengan judul "Pengaruh Model Example Non Example terhadap Kemampuan Pemahaman Konsep Bangun Datar pada Siswa Kelas IV di Sekolah Dasar"

\section{Metode Penelitian}

Penelitian ini menggunakan pendekatan kuantitatif dengan jenis penelitian eksperimen semu (quasy eksperiment). Desain yang digunakan dalam penelitian ini adalah nonequivalent kontrol group design (Sugiyono, 2017:79). Dalam pelitian ini terdapat Variable bebas (Variable prediktor) yaitu model pembelajaran Example Non Example dan Variable terikat (Variable Criteria) yaitu kemampuan pemahaman konsep matematis pada siswa kelas IV sekolah dasar.

Populasi penelitian ini ialah seluruh siswa kelas IV SD Negeri Kertasari I Kecamatan Rengasdengklok Kabupaten Karawang- Jawa Barat

Pada penelitian ini teknik pengumpulan data yang digunakan berupa instrument tes kemampuan pemahaman konsep. Tes ini terdiri atas tes awal (pre test) dan tes pasca tindakan (post test). Tes awal diberikan sebelum melakukan tindakan yang bertujuan untuk mengukur kemampuan pemahaman konsep matematis siswa sebelum diberikan tindakan. Sedangkan post test diberikan setelah dilakukan tindakan melalui model example non example yang bertujuan untuk mengukur pemahaman konsep siswa.

\section{Hasil Dan Pembahasan}

Berdasarkan hasil perhitungan data statistik kemampuan pemahaman konsep matematika siswa pada kelas eksperimen dalam bentuk distribusi frekuensi sebagai berikut:

Tabel 1 Nilai Siswa Kelas Eksperimen

\begin{tabular}{|c|l|c|}
\hline No & \multicolumn{1}{|c|}{ Statistik } & Kelas Eksperimen \\
\hline 1 & Jumlah siswa & 30 \\
\hline 2 & Jumlah Soal & 7 \\
\hline 3 & Jumlah Nilai & 2455 \\
\hline 4 & Rata-rata & 81.833 \\
\hline 5 & Standar Deviasi & 12.382 \\
\hline 6 & Varians & 153.316 \\
\hline 7 & Nilai Maksimum & 100 \\
\hline 8 & Nilai Minimum & 54 \\
\hline
\end{tabular}


Berdasarkan tabel 1 tentang hasil perhitungan data statistik diperoleh kemampuan pemahaman konsep matematis siswa pada kelas eksperimen dapat diuraikan sebagai berikut: Nilai rata-rata hitung $(X)$ sebesar 81,833; Variansi $=153,316$; Standar Deviasi $(S D)=12,382$, Nilai maksimum $=100$; Nilai minimum $=54$; Rentang nilai $($ Range $)=46$.

Untuk mengetahui kategori penilaian kemampuan pemahaman konsep matematika siswa yang diajarkan dengan menggunakan model pembelajaran Example Non Example dapat dilihat dari tabel kemampuan pemahaman konsep matematika siswa kelas IV SD yang tertera pada tabel 2 sebagai berikut:

Tabel 2 Rekapitulasi Penilaian Kemampuan Pemahaman Konsep Matematika Siswa Kelas Eksperimen

\begin{tabular}{|c|c|c|c|c|}
\hline No & Interval Nilai & Jumlah Siswa & Persentase & Kategori Penilaian \\
\hline 1 & $0 \leq$ SKKM $<45$ & 0 & $0 \%$ & Sangat Tidak Baik \\
\hline 2 & $45 \leq$ SKKM $<65$ & 4 & $13 \%$ & Tidak Baik \\
\hline 3 & $65 \leq$ SKKM $<75$ & 3 & $10 \%$ & Cukup Baik \\
\hline 4 & $75 \leq$ SKKM $<90$ & 15 & $50 \%$ & Baik \\
\hline 5 & $90 \leq$ SKKM $<100$ & 8 & $27 \%$ & Sangat Baik \\
\hline
\end{tabular}

Berdasarkan data pada tabel 2 diperoleh bahwa kemampuan pemahaman konsep matematika siswa pada kelas eksperimen yaitu kelas yang diajar dengan model pembelajaran Example Non Example memiliki nilai bervariasi atau berbeda antara siswa yang satu dengan yang lainnya. Nilai siswa mencakup terhadap 5 kategori berdasarkan penilaian kemampuan pemahaman konsep matematika siswa, yaitu sangat kurang baik, kurang baik, cukup baik, baik, dan sangat baik. Jumlah siswa yang memperoleh nilai sangat kurang baik tidak ada atau sebesar 0\%, yang memiliki kategori kurang baik sebanyak 4 siswa atau sebesar $13 \%$, yang memiliki nilai kategori cukup baik sebanyak 3 siswa atau sebesar $10 \%$, yang memiliki kategori baik sebanyak 15 siswa atau sebesar 50\%, yang memiliki nilai kategori sangat baik adalah sebanyak 8 siswa atau sebesar 27\%. Sesuai dengan kriteria ketuntasan minimum (KKM), siswa yang mencapai kategori tuntas sebanyak 23 siswa, sedangkan yang 7 siswa lainnya belum mencapai kategori tuntas.

Nilai pada kelas IVA sangat beragam atau berbeda antara siswa yang satu dengan yang lainnya, karena dapat kita lihat bahwa nilai variansi melebihi nilai tertinggi dari data di atas. Secara kuantitatif dapat dilihat pada tabel 3 berikut ini:

Tabel 3 Distribusi Frekuensi Data Kemampuan Pemahaman Konsep Matematika Siswa Kelas Eksperimen

\begin{tabular}{|c|c|c|c|c|}
\hline Kelas & Interval Kelas & F & Fr\% & Fk\% \\
\hline 1 & $53,5-61,5$ & 4 & 13 & 13 \\
\hline 2 & $61,5-69,5$ & 1 & 4 & 17 \\
\hline 3 & $69,5-77,5$ & 4 & 13 & 30 \\
\hline 4 & $77,5-85,5$ & 6 & 20 & 50 \\
\hline 5 & $85,5-93,5$ & 9 & 30 & 80 \\
\hline 6 & $93,5-101,5$ & 6 & 20 & 100 \\
\hline \multicolumn{2}{|c|}{ Jumlah } & $\mathbf{3 0}$ & $\mathbf{1 0 0}$ & \\
\hline
\end{tabular}

Berdasarkan nilai-nilai tersebut, dapat dilihat pada gambar 1 data kelas eksperimen sebagai berikut: 


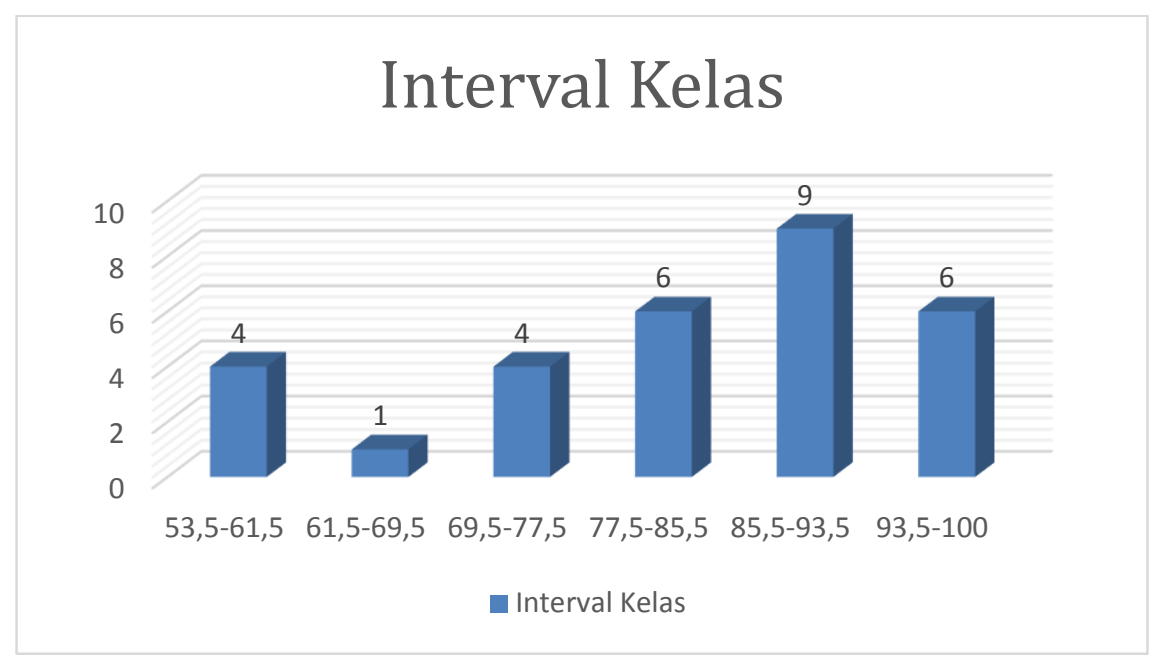

\section{Gambar 1 Kemampuan Pemahaman Konsep Matematika Siswa Kelas Eksperimen}

Berdasarkan tabel distribusi data kelompok di atas, pada perhitungan nilai tes terdapat perbedaan nilai pada masing-masing siswa, yakni terdapat siswa yang memiliki nilai tinggi, dan ada siswa yang memiliki nilai cukup tinggi, dan ada juga siswa yang memiliki nilai rendah. Jumlah siswa pada interval 53,5 - 61,5 adalah 4 siswa atau 13\%. Jumlah siswa pada interval nilai 61,5 - 69,5 adalah 1 siswa atau 4\%. Jumlah siswa pada interval nilai 69,5 - 77,5 adalah 4 siswa atau 13\%. Jumlah siswa pada interval nilai 77,5 - 85,5 adalah 6 siswa atau $20 \%$. Jumlah siswa pada interval nilai 85,5 - 93,5 adalah 9 siswa atau 30\%. Jumlah siswa pada interval nilai 93,5 - 101,5 adalah 6 siswa atau 20\%. Dari tabel juga diketahui bahwa dari 7 butir soal post test kemampuan pemahaman konsep matematika siswa yang telah diberikan kepada 30 siswa pada kelas eksperimen maka diperoleh nilai siswa yang terbanyak adalah antara nilai 85,5 - 93,5 yaitu berjumlah 9 siswa atau $30 \%$.

Perlu diketahui bahwa sampel yang terdapat pada kelas IV memiliki karakter yang beraneka ragam. Jika diukur dari kecerdasannya, ada siswa yang pintar, cukup pintar, dan kurang pintar. Jika diukur dari kecakapannya, ada siswa yang lamban dan ada pula siswa yang cepat tangkap dengan apa yang guru sampaikan. Hal tersebut terlihat dari ketika proses pengerjaan lembar kerja, terlihat siswa yang aktif, cukup aktif, hingga kurang aktif. Begitu pula ketika guru sedang menjelaskan materi, ada siswa yang cepat memahami dan ada pula yang lamban untuk memahami, sehingga guru perlu mengulang beerapa kali dalam menjelaskan materi tersebut. Hal tersebut juga telah terbukti dari hasil tes kemampuan pemahaman konsep matematika siswa yang berbeda-beda pada setiap masing-masing siswa.

Oleh karena itu, diperlukannya model pembelajaran yang dapat mendukung peningkatan kemampuan pemahaman konsep matematika siswa. Model pembelajaran Example Non Example yang diterapkan oleh peneliti pada kelas dinilai sangat membantu siswa dalam meningkatkan pemahaman yang dimiliki siswa, dimana siswa dapat memahami konsep lebih dalam lagi yakni dengan mencari informasi terkait materi, dan mendiskusikan pengetahuan masing- masing siswa miliki terkait materi di dalam kelompok ahli agar terbentuk suatu konsep seperti menemukan rumus keliling dan luas segi empat.

Berdasarkan hasil perhitungan data statistik kemampuan pemahaman konsep matematika siswa pada kelas kontrol dalam bentuk distribusi frekuensi dapat dilihat pada tabel 4: 
Tabel 4 Nilai Siswa Kelas Kontrol

\begin{tabular}{|c|l|c|}
\hline No & \multicolumn{1}{|c|}{ Statistik } & Kelas Kontrol \\
\hline 1 & Jumlah siswa & 32 \\
\hline 2 & Jumlah Soal & 7 \\
\hline 3 & Jumlah Nilai & 2369 \\
\hline 4 & Rata-rata & 74,031 \\
\hline 5 & Standar Deviasi & 14,075 \\
\hline 6 & Varians & 198,096 \\
\hline 7 & Nilai Maksimum & 93 \\
\hline 8 & Nilai Minimum & 59 \\
\hline
\end{tabular}

Berdasarkan hasil perhitungan data statistik kemampuan pemahaman konsep matematika siswa pada kelas kontrol dapat diuraikan sebagai berikut: Nilai rata-rata hitung $(X)$ sebesar 74,031; Variansi $=198,096$; Standar Deviasi $(S D)=14,075$; Nilai Maksimum $=93$; Nilai Minimum = 39; Rentangan Nilai $=54$.

Untuk mengetahui kategori penilaian kemampuan pemahaman konsep matematika siswa yang diajar dengan menggunakan model pembelajaran ceramah dapat dilihat dari tabel kemampuan pemahaman konsep matematika siswa kelas IVB yang tertera pada tabel 5 berikut ini:

Tabel 5 Rekapitulasi Penilaian Kemampuan Pemahaman Konsep Matematika Siswa Kelas Kontrol

\begin{tabular}{|c|c|c|c|c|}
\hline No & Interval Nilai & Jumlah Siswa & Persentase & Kategori Penilaian \\
\hline 1 & $0 \leq$ SKKM $<45$ & 2 & $6 \%$ & Sangat Tidak Baik \\
\hline 2 & $45 \leq$ SKKM $<65$ & 6 & $19 \%$ & Tidak Baik \\
\hline 3 & $65 \leq$ SKKM $<75$ & 8 & $25 \%$ & Cukup Baik \\
\hline 4 & $75 \leq$ SKKM $<90$ & 11 & $34 \%$ & Baik \\
\hline 5 & $90 \leq$ SKKM $<100$ & 5 & $16 \%$ & Sangat Baik \\
\hline
\end{tabular}

Berdasarkan data pada tabel 5, diperoleh bahwa kemampuan pemahaman konsep matematika siswa pada kelas kontrol yaitu kelas yang diajar dengan model pembelajaran ceramah memiliki nilai bervariasi atau berbeda antara siswa yang satu dengan yang lainnya. Nilai siswa mencakup terhadap 5 kategori berdasarkan penilaian kemampuan pemahaman konsep matematika siswa, yaitu sangat kurang baik, kurang baik, cukup baik, baik, dan sangat baik. Jumlah siswa yang memperoleh nilai sangat tidak baik sebanyak 2 siswa atau sebesar $6 \%$, yang memiliki kategori kurang baik sebanyak 6 siswa atau sebesar 19\%, yang memiliki nilai kategori cukup baik sebanyak 8 siswa atau sebesar 25\%, yang memiliki kategori baik sebanyak 11 siswa atau sebesar 34\%, yang memiliki nilai kategori sangat baik adalah sebanyak 5 siswa atau sebesar 16\%. Sesuai dengan kriteria ketuntasan minimum (KKM), siswa yang mencapai kategori tuntas sebanyak 16 siswa, sedangkan yang 16 siswa lainnya belum mencapai kategori tuntas.

Nilai pada kelas IVB sangat beragam atau berbeda antara siswa yang satu dengan yang lainnya, karena dapat kita lihat bahwa nilai variansi melebihi nilai tertinggi dari data di atas. Secara kuantitatif dapat dilihat pada tabel 6 berikut ini: 
The Effect of Non Example Example Models on the Ability to Understanding Flat Build Concepts in Class IV Students in Primary Schools

Tabel 6 Distribusi Frekuensi Data Kemampuan Pemahaman Konsep Matematika Siswa Kelas Kontrol

\begin{tabular}{|c|l|c|c|c|}
\hline Kelas & Interval Kelas & F & Fr\% & Fk\% \\
\hline 1 & $38,5-49,5$ & 2 & 6 & 6 \\
\hline 2 & $49,5-60,5$ & 0 & 0 & 6 \\
\hline 3 & $60,5-71,5$ & 14 & 44 & 50 \\
\hline 4 & $71,5-82,5$ & 8 & 25 & 75 \\
\hline 5 & $82,5-94,5$ & 8 & 25 & 100 \\
\hline \multicolumn{2}{|c|}{ Jumlah } & $\mathbf{3 2}$ & $\mathbf{1 0 0}$ & \\
\hline
\end{tabular}

Berdasarkan nilai-nilai tersebut, dapat dilihat pada gambar 2 data kelas kontrol sebagai berikut:

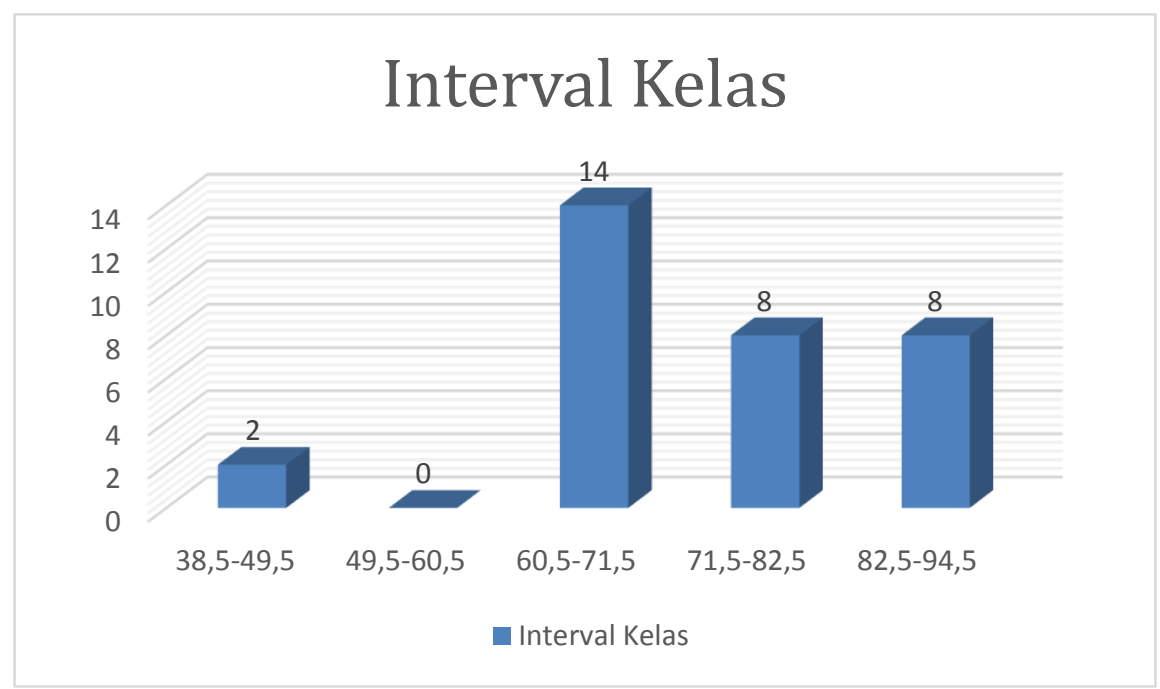

\section{Gambar 1 Kemampuan Pemahaman Konsep Matematika Siswa Kelas Kontrol}

Berdasarkan tabel distribusi data kelompok di atas, pada perhitungan nilai tes terdapat perbedaan nilai pada masing-masing siswa, yakni terdapat siswa yang memiliki nilai tinggi, dan ada siswa yang memiliki nilai cukup tinggi, dan ada juga siswa yang memiliki nilai rendah. Jumlah siswa pada interval 38,5 - 49,5 adalah 2 siswa atau 6\%. Jumlah siswa pada interval nilai 49,5 - 60,5 adalah 0 siswa atau 0\%. Jumlah siswa pada interval nilai 60,5 - 71,5 adalah 14 siswa atau 44\%. Jumlah siswa pada interval nilai 71,5 - 82,5 adalah 8 siswa atau 25\%. Jumlah siswa pada interval nilai 82,5 - 94,5 adalah 8 siswa atau 25\%. Dari tabel juga diketahui bahwa dari 7 butir soal post test kemampuan pemahaman konsep matematika siswa yang telah diberikan kepada 32 siswa pada kelas kontrol maka diperoleh nilai siswa yang terbanyak adalah antara nilai 60,5 - 71,5 yaitu berjumlah 14 siswa atau 44\%.

Perlu diketahui bahwa sampel yang terdapat pada kelas IVB memiliki karakter yang beraneka ragam. Jika diukur dari kecerdasannya, ada siswa yang pintar, cukup pintar, dan kurang pintar. Jika diukur dari kecakapannya, ada siswa yang lamban dan ada pula siswa yang cepat tangkap dengan apa yang guru sampaikan. Hal tersebut terlihat dari ketika proses pengerjaan lembar kerja, terlihat siswa yang aktif, cukup aktif, hingga kurang aktif. Begitu pula ketika guru sedang menjelaskan materi, ada siswa yang cepat memahami dan ada pula yang lamban untuk memahami, sehingga guru perlu mengulang beberapa kali dalam menjelaskan materi tersebut. Hal tersebut juga telah terbukti dari hasil tes kemampuan pemahaman konsep matematika siswa yang berbeda-beda pada setiap masing-masing siswa.

Oleh karena itu, diperlukannya model pembelajaran yang dapat mendukung peningkatan kemampuan pemahaman konsep matematika siswa. Model pembelajaran ceramah yang diterapkan oleh guru pada kelas diharapkan mampu untuk membantu kemampuan pemahaman konsep matematika siswa. Melalui model pembelajaran yang digunakan, guru dapat 
menyampaikan materi secara terstruktur, sehingga siswa dapat lebih mudah memahami pelajaran dengan baik.

Uji persyaratan yang digunakan adalah uji normalitas dan uji homogenitas. Uji normalitas untuk melihat apakah data suatu hasil belajar siswa berdistribusi normal atau tidak. Uji normalitas menggunakan uji Liliefors sedangkan uji homogenitas dimaksudkan untuk melihat homogen atau tidaknya data kemampuan pemahaman konsep matematika siswa tersebut. Maka dalam hal ini digunakan uji -F. Uji persyaratan ini dilakukan untuk memenuhi persyaratan yaitu uji-t. Kedua uji tersebut adalah sebagai berikut:

1. Uji Normalitas

Salah satu teknik analisis dalam uji normalitas adalah teknik analisis Lilliefors. Uji normalitas data dimaksudkan untuk mengetahui apakah data-data hasil penelitian memiliki sebaran data yang berdistribusi normal dan hipotesis tandingan bahwa populasi berdistribusi tidak normal. Sample berdistribusi normal jika dipenuhi $L_{\text {hitung }}<L_{\text {tabel }}$ pada taraf $a=0,05$. Sedangkan sampel berdistribusi tidak normal jika di penuhi $L_{\text {hitung }}>L_{\text {tabel }}$. Hasil analisis normalitas untuk masing-masing sub kelompok dapat dijelaskan sebagai berikut:

Tabel 7 Hasil Uji Normalitas Data Kelompok Eksperimen

\begin{tabular}{|l|l|l|l|l|}
\hline Data & Mean & $\mathrm{L}_{\text {hitung }}$ & $\mathrm{L}_{\text {tabel }}$ & Keterangan \\
\hline Pre test & 51,767 & 0,127 & 0,162 & \multirow{2}{*}{ Berdistribusi Normal } \\
\cline { 1 - 4 } Post test & 81,833 & 0,102 & 0,162 & \\
\hline
\end{tabular}

Berdasarkan data tabel 7 maka dapat diketahui Lhitung untuk kemampuan pemahaman konsep matematika siswa pada kelas eksperimen sebelum diberi perlakuan adalah 0,127 (Pre test) dan setelah diberi perlakuan adalah 0,102 (Post test). Untuk menguji hipotesis tingkat normalitas terlebih dahulu dilakukan dengan menggunakan bantuan tabel nilai kritis $L$ untuk uji normalitas. Penentuan Ltabel disesuaikan dengan banyaknya ukuran sampel yakni 30 siswa dan $a=0,05$, maka didapat nilai Ltabel sebesar 0,162 . Suatu data dikatakan berdistribusi normal apabila Lhitung < Ltabel. Sebaliknya suatu data dikatakan tidak normal apabila Lhitung $>$ Ltabel. Dalam hal ini data yang diperoleh dari soal kemampuan pemahaman konsep matematika siswa pada kelas eksperimen, baik sebelum dan sesudah dibeirkan perlakuan menunjukan bahwa kedua data berdistribusi normal. Data yang diperoleh dari instrumen soal kemampuan pemahaman konsep yaitu Lhitung $(0,102)<(0,162)$ Ltabel. Maka dapat disimpulkan bahwa data kemampuan pemahaman konsep matematika siswa pada kelas eksperimen berdistribusi normal. Sedangkan untuk kelas kontrol dapat dilihat pada tabel 8 berikut:

Tabel 8 Hasil Uji Normalitas Data Kelompok Kontrol

\begin{tabular}{|l|l|l|l|l|}
\hline Data & Mean & $\mathrm{L}_{\text {hitung }}$ & $\mathrm{L}_{\text {tabel }}$ & Keterangan \\
\hline Pre test & 52,344 & 0,127 & 0,162 & Berdistribusi Normal \\
\cline { 1 - 4 } Post test & 81,833 & 0,102 & 0,162 & \\
\hline
\end{tabular}

Dari data diatas diperoleh nilai Lhitung pada kelas kontrol sebelum dilakukan pembelajaran adalah 0,109. Sedangkan setelah dilakukan perlakuan Lhitungnya adalah 0,135 penentuan Ltabel disesuaikan dengan banyaknya ukuran sampel yakni 32 siswa dan $a=0,05$, maka didapat nilai Ltabel sebesar 0,157. Dalam hal ini data yang diperoleh dari soal kemampuan pemahaman konsep matematika siswa pada kelas kontrol baik sebelum dan sesudah diberikan perlakuan menunjukan bahwa kedua data berdistribusi normal, dikarenakan Lthitung (pre test) < Ltabel $(0,109<0,157)$. Lthitung (post test) $(0,135<0,157)$. 
The Effect of Non Example Example Models on the Ability to Understanding Flat Build Concepts in Class IV Students in Primary Schools

\section{Uji Homogenitas}

Berdasarkan perhitungan diperoleh varians (pre test) kelas eksperimen dan nilai varians (pre test) kelas kontrol masing-masing sebesar 137,426 dan 76,748. Untuk menghitung Ftabel diperoleh dari daftar nilai kritik pada distribusi $\mathrm{F}$ dengan $\mathrm{dk}$ penyebut $=(32-1=31)$, $\mathrm{dk}$ pembilang $=(30-1=29)$ dan taraf nyata $a=0,05$ diperoleh $F_{0,05}(29,31)=1,844$. Sehingga diperoleh nilai Fhitung $=1,790$ dan Ftabel $=1,844$. Berdasarkan nilai Fhitung dan Ftabel yang diperoleh dapat disimpulkan bahwa Fhitung < Ftabel $(1,790<1,844$ berdasarkan nilai Fhitung dan Ftabel dapat disimpulkan bahwa varians kedua sampel tersebut adalah homogen.

Sedangkan nilai varians (post test) kelas eksperimen dan nilai varians (post test) kelas kontrol masing-masing sebesar 153,316 dan 198,096. Untuk menghitung $F_{\text {tabel }}$ diperoleh dari daftar nilai kritik pada distribusi $\mathrm{F}$ dengan dk penyebut $=(32-1=31)$, dk pembilang $=(30$ $1=29)$ dan taraf nyata $a=0,05$ diperoleh $F_{0,05}(29,31)=1,844$. Berdasarkan nilai Fhitung dan Ftabel yang diperoleh dapat disimpulkan bahwa Fhitung $<$ Ftabel $(1,292<1,844)$ berdasarkan nilai Fhitung dan Ftabel dapat disimpulkan bahwa varians kedua sampel tersebut adalah homogen. Hasil perhitungan homogenitas dan kelas eksperimen dan kelas kontrol dapat dilihat pada tabel 9 dibawah ini, sedangkan perhitungan selengkapnya dapat dilihat pada tabel 9.

Tabel 9 Hasil Perhitungan Homogenitas Kelas Eksperimen dan Kelas Kontrol

\begin{tabular}{|c|l|l|l|l|}
\hline Kelompok pre test & Varians & Fhitung & Ftabel & Keterangan \\
\hline Eksperimen & 137,426 & 1,790 & 1,844 & Homogen \\
\cline { 1 - 2 } Kontrol & 76,748 & & & \\
\hline Kelompok post test & & & 1,844 & Koterangan \\
\hline Kksperimen & 153,316 & 1,292 & & \\
\hline Kontrol & 198,096 & & & \\
\hline
\end{tabular}

Untuk melihat pengaruh dari model pembelajaran yang digunakan terhadap kemampuan pemahaman konsep matematika siswa digunakan uji-t. Terdapat pengaruh model pembelajaran Example Non Example terhadap kemampuan pemahaman konsep matematika siswa di kelas IV SDN Kertasari I. Hal ini dibuktikan dengan hasil uji-t yang diperoleh $=2,311$ dan 2,000. Hal tersebut membuktikan bahwa nilai rata-rata hasil kemampuan pemahaman konsep matematika siswa dengan menggunakan model pembelajaran Example Non Example lebih baik dibanding dengan nilai rata-rata hasil kemampuan pemahaman konsep matematika siswa dengan menggunakan model pembelajaran Ceramah.

Model pembelajaran Example Non Example lebih baik dan lebih efektif untuk diterapkan dalam kegiatan pembelajaran matematika khususnya materi segi empat (persegi panjang, persegi, jajargenjang, belah ketupat, layang-layang dan trapesium), karena telah terbukti dapat meningkatkan kemampuan pemahaman konsep matematika siswa. Hal ini disebabkan karena model pembelajaran Example Non Example bertujuan untuk mendorong siswa agar belajar kritis dengan jalan memecahkan permasalahan-permasalahan yang terkandung dalam contoh-contoh gambar yang telah dipersiapkan terlebih dahulu. Model pembelajaran Example Non Example merupakan sebuah langkah untuk mensiasati agar siswa dapat mendefenisikan konsep. Adapun strategi yang biasa digunakan bertujuan untuk mempersiapkan siswa secara cepat dengan menggunakan 2 hal yang terdiri dari Example (contoh akan suatu materi yang sedang dibahas) dan Non Example (contoh akan suatu materi yang tidak sedang dibahas), dan meminta siswa untuk mengklasifikasikan keduanya sesuai dengan konsep yang ada. Sedangkan model pembelajaran Ceramah merupakan model pembelajaran yang dilakukan dengan komunikasi satu arah sehingga situasi belajarnya berpusat pada pengajar (teacher center). Hal ini berarti guru mengajar untuk memberikan informasi secara lisan dan data kepada siswa tanpa ada usaha mengembangkan keterampilan. Dalam pembelajaran ini, peran siswa adalah sebagai penerima informasi yang pasif. 
Dari penelitian ini, maka peneliti dapat simpulkan bahwa terdapat pengaruh model pembelajaran Example Non Example terhadap kemampuan pemahaman konsep matematika siswa kelas IVA SD Negeri Kertasari 1 Tahun Akademik 2018/2019. Dan juga terdapat terdapat pengaruh model pembelajaran Ceramah terhadap kemampuan pemahaman konsep matematika siswa kelas IVB SD Negeri Kertasari 1 Tahun Akademik 2018/2019. Namun pengaruh model pembelajaran Example Non Example terhadap kemampuan pemahaman konsep matematika siswa kelas IVA SD Negeri Kertasari 1 Tahun Akademik 2018/2019 lebih baik dibanding dengan pengaruh model pembelajaran Ceramah terhadap kemampuan pemahaman konsep matematika siswa kelas IVB SD Negeri Kertasari 1 Tahun Akademik 2018/2019.

\section{Kesimpulan}

Simpulan dari penelitian ini ialah:

1. Kemampuan pemahaman konsep matematika siswa yang diajar dengan menerapkan model pembelajaran Example Non Example memperoleh rata- rata 81,833 dengan variansi 153,316 dan standar deviasi 12,382.

2. Kemampuan pemahaman konsep matematika siswa yang diajar dengan menerapkan model pembelajaran Ceramah memperoleh rata-rata 74,031 dengan variansi 198,096 dan standar deviasi 14,075.

3. Terdapat pengaruh model pembelajaran Example Non Example terhadap kemampuan pemahaman konsep matematika siswa di kelas SD Negeri Kertasari 1. Hal ini dibuktikan dengan hasil uji-t yang diperoleh $=2,311$ dan 2,000.

\section{Daftar Pustaka}

Arends, Richard. I. 2008. Learning To Teach Belajar untuk Mengajar. Yogyakarta: Pustaka Belajar

Arikunto, Suharsimi. 2014. Prosedur Penelitian Suatu Pendekatan Praktis. Jakarta: Rineka Cipta.

BSNP. 2006. Standar Isi untuk Satuan Pendidikan Dasar dan Menengaj, Standar Kompetensi dan Kompetensi Dasar SD/MI. Jakarta: Depdiknas

Dimyati dan Mudjiono. 2006. Belajar Dan Pembelajaran. Jakarta: Rineka Cipta.

Hamalik, Oemar. 2003. Proses belajar Mengajar. Jakarta: PT. Bumi Aksara

Huda, Miftahul. 2014. Model-Model Pengajaran dan Pembelajaran (Isu-Isu Metodis Dan Paradigmatis). Yogyakarta: Pustaka Pelajar.

Joyce Burce, Marsha Weil, \& Emily Calhoun. (2009). Model of teaching. Diterjemahkan oleh Achmad Fawaid dan Ateilla Mirza. Englewood Cliffs, New Jersey : Pretice Hall, Inc

Shadiq, Fajar. 2014. Pembelajaran Matematika ; Cara Meningkatkan Kemampuan Berpikir Siswa. Yogyakarta: Graha Ilmu

Sugiyono. 2013. Metode Penelitian Pendidikan. Bandung: Tarsito

Suprijono, Agus. (2009). Cooperative learning. Yogyakarta: Pustaka Pelajar

Zubaidah Amir dan Risnawati. 2016. Psikologi Pembelajaran Matematika. Yogyakarta: Aswaja Pressindo 